\title{
Biserka Rukavina
}

E-mail: biserka@pfri.hr

\section{Loris Rak}

E-mail: 1rak@pfri.hr

University of Rijeka, Faculty of Maritime Studies, Studentska 2, 51000 Rijeka, Croatia Silvana Buneta

E-mail: buneta.silvana@gmail.com

\section{Legal framework for establishing a single maritime transport space without barriers}

\begin{abstract}
Summary
This paper provides an overview of activities of the European Commission for establishing a single European maritime transport space and indicates whether and to what extent the adopted strategy documents have established their operations in practice.

Directive 2010/65/EU of the European Parliament and of the Council on reporting formalities for ships arriving in and/or departing from ports of the Member States and repealing Directive 2002/6/ EC, as well as Directive 2002/59/EC of the European Parliament and of the Council establishing the Community vessel traffic monitoring and information system, which represent significant legislative achievements of the European Union in the process of reducing administrative burdens to which ships are exposed in the maritime transport, are particularly analyzed. Reasons for amending Directive 2002/59/EC are especially explained.

In the last part of the paper, authors review the achievements of the Republic of Croatia regarding the implementation of measures for the establishment of a single European maritime transport space. Based on the results of a comparative overview of solutions contained in the Directives and Croatian bylaws, authors point to the existence of non-compliance and to the need for further action.
\end{abstract}

Key words: single European maritime transport space, Directive 2010/65/EU, 2002/59/EC, the Croatian legal framework.

\section{Introduction}

Over $70 \%$ of goods imported or exported by the European Union pass through the sea ports and $37 \%$ of those goods are exchanged within the European Union.[14] These data indicate the importance of maritime transport for the functioning of the EU 
internal market and its trade with the rest of the world. However, ships involved in the maritime transport are exposed to many complex administrative checks and procedures prescribed by international, European and national regulations regarding safety and security, customs, tax, immigration, health care, etc. For these reasons, competent public administration authorities require a number of documents and information relating to these areas for ships arriving in and/or departing from ports. Practice shows that requests and procedures necessary for their fulfillment are repeated, they take a lot of time and create additional costs and delay to the ships or the goods in port, thus making maritime transport less attractive and less competitive.

Although Article 28 of the Treaty on the Functioning of the European Union allows free movement of goods within the customs territory of the European Union, the single internal market in the maritime transport has not been fully realized.1[15] Ships leaving the territorial waters of a Member State shall be deemed to cross the external EU borders, meaning that they came out of the EU customs territory and therefore are subject to customs checks. Upon arrival at the port of another Member State, they are subjected to repeated customs control unless the vessel is not subject to the rules of scheduled service. Although these checks are necessary for safety and financial reasons, they generate additional costs and lead to delayed delivery of goods. Therefore, the European Commission seeks through a variety of initiatives to implement measures to reduce customs formalities and administrative burdens accompanying reporting of formalities, all these in order to make maritime transport an attractive alternative to other modalities of transport. At the same time, EU legislative acts are being adopted so that the objectives set by the strategic documents may be implemented in Member States' legislation and take hold in practice.

\section{Strategic documents of the European Union on the establishment of a single maritime transport space without barriers}

The idea of creating a European single maritime transport space without barriers has been present among the actions of EU bodies for many years. According to its powers and the right of initiative, the European Commission proposes the adoption of a legal act of the European Parliament and the Council with the prior implementation of extensive consultation in order to take into account participants' point of view. Apart from preparing and proposing regulations, the Commission makes strategic and action documents containing initiatives and measures for future actions in a particular area.

According to Article 28 of The Treaty on the Functioning of the European Union, The Union shall comprise a customs union which shall cover all trade in goods and which shall involve the prohibition between Member States of customs duties on imports and exports and of all charges having equivalent effect, and the adoption of a common customs tariff in their relations with third countries. 
In the text here following, we will review strategic documents in the domain of maritime transport that the European Commission has adopted in order to create preconditions for strengthening the competitiveness of maritime transport and the establishment of a single maritime transport space by reducing and simplifying administrative procedures.

\subsection{Communication and action plan with a view to establishing a European maritime transport space without barriers}

Document Communication and action plan with a view to establishing a European maritime transport space without barriers was adopted by the European Commission in 2009. [9] The Introduction of the document points out that the maritime transport is "the victim" of complex and demanding administrative procedures even when vessels ply only between EU ports and the cargo consists of Community goods only. The Commission considers complex administrative requirements related to maritime transport as the main brake on maritime development; the solution is to create a European maritime transport space without barriers. One of the short-term measures about to be used in order to achieve the above described goal is the measure on simplification of customs formalities for vessels only sailing between EU ports. Another short-term measure related to the development of systems that will give guidelines for speeding up documentary checks was related to animal and plant products carried between the EU ports, and the last measure in the group of short-term measures is directed to the rationalization of documents required under different legislative bodies.

In addition to the above short term measures, appropriate medium-term measures were also presented in order to be implemented at the EU level. The first among these measures relates to the simplification of administrative formalities for vessels sailing between the EU ports, yet having a call in a third country or a free zone. The simplification is based on the modernized (amended) European Customs Code and the implementation of the national Single Window. An extremely important measure aims at enhancing the electronic data transmission.

Insufficient operational co-ordination in ports between various administrative services at the port level as well as at the national level have been reported as a major source of unjustified costs for shipping as well as a source of inefficiency, all of them related to the implementation of adopted measures. Member States hold the responsibility for the implementation of measures and they should invite local authorities to improve operational co-ordination by making sure that the sequence of administrative steps does not create unnecessary delays due to vessel's long stay in port. 


\subsection{White Paper - Roadmap to a Single European Transport Area - Towards a competitive and resource efficient transport system}

"White Paper - Roadmap to a Single European Transport Area - Towards a competitive and resource efficient transport system" of 2011 highlights transport as being fundamental for the economy; transport is global and therefore an effective action requires strong international cooperation. [1] The Commission asks for the establishment of a "Blue Belt" in order to simplify the formalities for ships travelling between the EU ports. The White Paper advocates for the establishment of a European Transport Area by eliminating all residual barriers between different modes of transport and national borders. A Single European Transport Area should ease the movement of citizens and freight, reduce costs and enhance the sustainability of the European transport. Maritime transport is discussed in Measure 29 where it is stated that the European Union together with the International Maritime Organization and other international organizations should strive for uniform application of high standards of safety, security protection, environment protection and working conditions.

Safety of maritime transport implies the establishment of the legal, administrative and enforcement framework. The SafeSeaNet Information System is considered to be the core of all relevant maritime information tools supporting maritime transport safety and security, as well as the protection from ship-source pollution. It will thus provide the essential contribution to the establishment of a common information sharing environment for the surveillance of the EU maritime domain and support the creation of a common maritime space. In the Plan for a Single European Transport Area, the Commission repeatedly highlights the importance of the initiative to create a European maritime transport space without barriers and the need for further development of the "Blue Belt". The aim is to achieve full interoperability between ICT systems in the waterborne sectors and to guarantee the monitoring of vessels and freight.

\subsection{Single Market Act II Together for new growth}

The Commission had continued the action aimed at establishing a Single European Transport Area without barriers by having adopted the Single Market Act II Together for new growth in 2012 [8]. The Single Market Act II is a new step in the process of the Single Market integration. The main engine of growth, employment and consumer confidence is considered to be developing a fully integrated network of rail, sea and air transport; encouraging cross-border mobility of citizens and the business sector; support the development of digital economy and the strengthening of social entrepreneurship cohesion and consumer confidence. As in the previous documents and initiatives in the Single Market Act II, the "Blue Belt" is recognized as a key action that would be based on the legislative and non-legislative initiatives that would reduce the administrative burden for intra-EU maritime transport to a level that is comparable to that of other transport modes and create a Single European Transport Area. The competitiveness 
and attractiveness of maritime transport is subject, among other things, to the quality of port services that must be available, effective and reliable. The Commission had made further efforts so that in 2013 it drafted the Regulation establishing a framework on market access to port services and financial transparency of ports. The primary objectives of this Regulation are to strengthen the competitiveness of European ports and the growth of the port sector in general through the improvement of port services, reduction of administrative formalities in ports as well as by increasing financial transparency of ports. The European Parliament has proposed a number of amendments to the text of the Regulation, starting with the title. The Parliament proposes that the regulation should be entitled "Regulation establishing a framework for the organization of port services and for financial transparency of ports". ${ }^{2}$ Although the text of the Regulation mentioned the year 2015 as a possible date of application, the regulation has not been adopted yet.

\subsection{Communication from the Commission - Blue Belt, a Single Transport Area for shipping}

The Blue Belt is an area where vessels can operate freely within the EU internal market with a minimum of administrative burden. Some efforts have been made in order to reduce administrative burdens for ships sailing exclusively between EU ports and transporting goods of the Union. However, great majority of the ships deals with the ports of third countries and transport non-Union goods. It is exactly this type of maritime transport services that necessarily require mechanisms and measures to be found for the reduction or elimination of administrative barriers in order to enhance the attractiveness and competitiveness of maritime transport. In addition to market benefits, the implementation of measures envisaged in the Communication from the Commission - "Blue Belt" would support active implementation of environmental policy.

The measures encompassed by the Communication from the Commission - "Blue Belt" - a single transport area for shipping, are aimed at improving the program of regular marine lines and the establishment of a mechanism which would facilitate administrative procedures, including harmonization of customs measures in the case of ship's docking in third countries ports.[10] The status of the goods carried on-board needs to be known to the customs in order for appropriate customs supervision to be determined. The regulations distinguish two possible statuses of goods: the EU status of goods and the non - EU status of goods. The data on the status of goods would be stated in the electronic consignment note /bill of freight, the so-called eManifest. The introduction of the eManifest providing information on the status of the goods to the customs authorities at the port of discharge would enable smooth passing of goods ha-

$\overline{2}$ On 08th March 2016, the European Parliament adopted the total number of 136 amendments, www.europarl.europa.eu 
ving the EU status. If the status of the goods of the Union is confirmed after submitting the eManifest, the goods on board will not be subject to further customs checks except for exceptional inspections. Using a unified cargo manifest in electronic form represents a great relief to shippers and shipping companies as well as simplification of the procedure for customs authorities. The customs authority in the next port where the Union-status goods are planned to deploy, monitors the information contained in the eManifest and ensures fast flow of goods on the basis of its status.

The eManifest would refer to the information on the cargo that was picked in the previous port, and this would enable an additional factor regarding the monitoring of its harmonization with fiscal and safety requirements of the EU. If the ship docks in the port of a third country between two ports of the European Union, yet the goods of the Union remain on board, those goods will retain their status as reported after departure from the last port in the European Union.

The eManifest notes that the goods which have been loaded in ports outside the European Union are not considered the Union-status goods. In order to achieve the planned benefits of introducing eManifest in the maritime transport, it is necessary to provide a unique approach to its application at the EU level.

\section{Legislative acts of the European Union on the establishment of a single space for maritime transport without barriers}

\subsection{Directive 2002/59/EC of the European Parliament and of the Council of establishing a Community vessel traffic monitoring and information system and repealing Council Directive 93/75/EEC}

Directive 2002/59/EC of the European Parliament and of the Council of establishing a Community vessel traffic monitoring and information system and repealing Council Directive 93/75/EEC had been brought in order to set the vessel traffic monitoring and information system for the purpose of enhancing safety and efficiency of the maritime traffic, improvement of response of competent bodies in case of incidents or accidents or potentially dangerous situations at sea, including search and rescue operations and contributing to a better prevention and detection of pollution by ships.[3]

Directive 2002/59/EC applies according to two critera: the first criteria applies to gross tonnage of the ship, it excludes the application on ships having less than 300 gross tonnes, unless stated otherwise. The second criteria apllies to the kind of the ship. According to the Article 2, paragraph 2 of Directive 2002/59/EC, the regulations from the Directive shall not apply to:

(a) warships, naval auxiliaries and other ships owned or operated by a Member State and used for non-commercial public service;

(b) fishing vessels, traditional ships and recreational craft with a length of less than 45 metres;

(c) bunkers below 5000 tons, ships' stores and equipment for use on board ships. 
Regulation under c) was changed by Directive 2009/17/EC of the European Parliament and of the Council regarding change of Directive 2002/59/EC in a manner that the exception from applying the Directive 2002/59/EC refers to bunkers below 1000 tons (Article 1, paragraph 1, point b of the Directive 2009/17/EZ).[4]

Article 4 of the Directive 2002/59/EZ provides timelines for notification of the demanded data. The operator, agent or master of a ship bound for a port of a Member State shall notify the information to the port authority of the Member State at least twenty-four hours in advance or, at the latest, at the time the ship leaves the previous port, if the voyage time is less than twenty-four hours. If the port of call is not known or is changed during the voyage, is should be notified as soon as this information is available. Such a solution has been completely adopted in Directive 2010/65 / EU on the official application procedures for ships arriving in port and/or departing from ports of the Member States and repealing Directive 2002/6/EC.[6]

Specific rules were laid down for the submission of data on dangerous or polluting goods, having in mind that a special procedure is provided on ship's departure from the port and on her arrival at the port of a Member State. In the case of ship's departure from the port, the required information listed in Annex I point 3 shall be submitted to the competent authority at the time of departure at the latest. For a ship coming from a port located outside the EU area, Article 13, paragraph 2 of Directive 2002/59/ EC provides that the operator, agent or master of a ship shall submit the requested information at the latest upon departure from the loading port or as soon as the port of destination or the location of the anchorage is known, if this information is unavailable at the moment of departure.

The provision of Article 15 of Directive 2002/59/EC regulating exemptions is particularly important. Ships providing scheduled service between the ports of Member States may request the other Member States to grant them exemption from that service.

Member States may exempt scheduled services performed between ports located in their territory from the requirement laid down in Article 13 of Directive 2002/59/ $\mathrm{EC}$, but the following conditions must be met cumulatively: a) the company may operate the scheduled services exclusively by ships referred in the list concerned for the exemption; b) the company must establish a system to ensure that, upon request 24 hours a day and without delay, the said information can be sent to the competent authority electronically.

The above mentioned exemption may also be approved in case when scheduled service is operated between two or more States, of which at least one is a Member State. Any of the Member States involved may request from the other Member States an exemption to be granted to that service.

The rule has been changed. Two new conditions have been added by Directive 2009/17/EC, and the company must obey them continuously in order to use the exemption. The first one provides for any deviations from the estimated time of arrival at the port of destination or pilot station of three hours or more to be notified by the ship to 
the port of arrival or to the competent authority, and the other one restrains obtaining the exemptions, meaning that they are only granted to individual vessels as regards a specific service.

Directive 2009/17/EC, provides the definition of "scheduled service" which means a series of ship crossings operated so as to serve traffic between the same two or more ports, either according to a published timetable or with crossings so regular or frequent that they constitute a recognizable systematic series (Article 1, paragraph 2, point c of Directive 2009/17/EZ).

The State is obliged to check whether the company continuously meets the conditions required for obtaining the benefit, and if it finds that an omission has been made, the State shall withdraw the benefit of the exemption.

Further change refers to the establishment of the maritime information exchange system on the national and local levels by using the 'SafeSeaNet' system; therefore Annex III of Directive 2002/59/EC has been changed. Annex III describes the general concept and the 'SafeSeaNet' organization system which is composed of a network of national SafeSeaNet systems in Member States and a SafeSeaNet central system acting as a nodal point. According to the demands of Directive 2009/17/EZ, it is necessary for the Member States to establish a national competent authority responsible for the management of the national system while the Commission is responsible for the central SafeSeaNet system.

Directive 2009/17/EZ introduces one new document - "Interface and functionalities control document" which describes in detail the performance requirements and procedures applicable to the national and central element of the SafeSeaNet system. Among other things, the "Interface and functionalities control document" includes rules for security specifications for data transmission and exchange, and the archiving of information at the national and central levels. The documents specially indicate the means of storage and the availability of the information on dangerous or polluting goods concerning scheduled services to which an exemption has been granted in accordance with Article 15 of Directive 2002/59/EC.

Starting from the day of bringing the Directive 2002/59/EC, the SafeSeaNet as the Union's system for monitoring maritime traffic has gained technological improvements that caused technical integration of different systems and applications. Special progress has been made in the development of interoperable system used to exchange the information by which it is possible to consolidate information from the SafeSeaNet system, information from other Union's systems for monitorning and surveilance (CleanSeaNet, European Union Cooperative Data Centre for Long Range Identification and Tracking and Thetis) and information from other foreign systems, which further enhances the integration of maritime services. In order to evaluate the achieved improvements, it needed to be intervened in the content of Directive 2002/59/EC. Based on the above described, in 2014 the Commission adopted Directive 2014/100/EU that changed the Directive 2002/59/EC.[5] The change relates to the replacement of Annex III by a new expanded content. The change was needed for several reasons. First of all, 
it was necessary to extend the list of legal acts which contain the data and information that can be used for centralized system of the SafeSeaNet. Directive 2002/59/EC only refers to Directive 2000/59/EC of the European Parliament and of the Council on port reception facilities for ship-generated waste and cargo residues. The revised Annex III added three new directives, namely: Directive 2005/35/EC of the European Parliament and the Council on ship-source pollution and on the introduction of penalties for infringements, Directive 2009/16/EC of the European Parliament and of the Council on port State control and Directive 2010/65/EU of the European Parliament and the Council on reporting formalities for ships arriving in and/or departing from ports of the Member States.

It is also necessary to redefine the responsibilities of the Member States to maintain a national SafeSeaNet system and the responsibilities of the Commission to maintain the Central SafeSeaNet system. They also expanded the task of the high level steering group (management).

\subsection{Directive 2010/65/EU on reporting formalities for ships arriving in and/ or departing from ports of the Member States and repealing Directive 2002/6/EC}

Directive 2010/65/EU on reporting formalities for ships arriving in and/or departing from ports of the Member States and repealing Directive 2002/6/EC is adopted as one of the measures of the European Union for establishing the "Blue belt" - a single maritime transport space without barriers. Regulation from Article 1 of Directive 2010/65/EU explains the purpose of its adoption, and that is "to simplify and harmonize the administrative procedures applied to maritime transport by making the electronic transmission of information standard and by rationalizing reporting formalities".[6] According to the above mentioned, it is clear that the Directive 2010/65/EU exclusively deals with manners of gathering, simplifying and harmonizing the procedures of their exchange, without prejudice to the nature and the content of requested information.

Regulations of Directive 2010/65/EU deal with different issues related to the offcial procedure of ships' registration (reporting of formalities). The field of applying Directive 2010/65/EU is defined by Article 1, paragraph 2: it shall apply only to maritime transport for ships arriving in and ships departing from ports situated in Member States, and the term "Ship" has a broad meaning and represents any seagoing object at sea, which means vessels and yachts. Directive 2010/65/EU does not create limitiations regarding its application according to the gross tonnage or type of a ship, but allows certain exemptions from its application. According to Article 9 of the Directive 2010/65/ EU, ships operating between ports situated in the customs territory of the Union, but which do not come from the port situated outside the port from that customs area, call at or are headed towards a port situated outside that territory or a free zone subject to type I controls under customs legislation, are exempt from the obligation to send the 
information referred to in the FAL forms. Nevertheless, the above mentioned exemption is not absolute without prejudice to the applicable legal acts of the Union and the possibility that Member States may request information in the FAL forms (forms from 1 to 6) which is necessary to protect internal order and security and to enforce customs, fiscal, immigration, environmental, or sanitary laws.

According to Article 5 of Directive 2010/65/EU, Member States are obliged to establish a national single window that links SafeSeaNet, e-Customs and other electronic systems. A single window shall be the place where all information is reported once and made available to various competent authorities of the Member States. There are three categories of official reporting of the formalities: official procedure of reporting formalities resulting from legal acts of the Union, official procedure of reporting formalities resulting from international legal instruments and official procedure of reporting formalities resulting from national legislation.

Directive 2010/65/EU defines the persons obliged to deliver the required information and time limits for their delivery. Master or any other person duly authorized by the ship operator provides notification, and that is at least 24 hours before the ship arrives in the port or, at the latest, at the time the ship leaves the previous port, if the voyage time is less than 24 hours. If the port of call is not known or it is changed during the voyage, according to the official procedure, as soon as the required information is available (Article 4 of the Directive).

Having in mind that maritime traffic has the international character, during adopting the Directive 2010/65/EU, certain solutions defined by the International Maritime Organization (IMO) and relevant for this area had to be taken in consideration. According to the Convention on Facilitation of International Maritime Traffic, the so-called FAL forms are adopted and used.[11] According to the above mentioned, it is necessary to define mutual relationship between those forms and the electronic exchange system on the EU level. Regulation from Article 7 of Directive 2010/65/EU sets that the Member States shall accept FAL forms to report formalities. ${ }^{3}$ It must be highlighted that Directive 2010/65/EU must call for the FAL form version valid at that moment and therefore the Commission must continuously follow the work of the Facilitation Committee of the International Maritime Organization and suggest changes and supplements of the Directive itself.

Member States shall, in accordance with Article 8 of Directive 2010/65 EU, take the necessary measures to ensure the confidentiality of commercial and other confidential information exchanged in accordance with this Directive. The Directive itself does not define what is supposed to be considered as confidential information and does not refer to the legal act which should be the basis for such an opinion to be made. The lack

3 According to the Convention on Facilitation of International Maritime Traffic, there are 7 so called FAL forms: General Declaration (FAL form 1), Cargo Declaration (FAL form 2), Ship's store declaration (FAL form 3), Crew's Effects declaration (FAL form 4), Crew List (FAL form 5), Passenger List (FAL form 6), Dangerous Goods List (FAL form 7). 
of a clear solution, of course, leaves room for different Member States to regulate this issue differently, and that is contrary to the objectives set in the strategic documents of the Commission and even in the Directive 2010/65/EU itself.

The Commission shall compose the Report regarding the functioning of this Directive and deliver it to the European Parliament and the Council, including potential difficulties in its implementation and non-harmonization. According to Article 15 of Directive 2010/65/EU, the Commission also reports on:

- feasibility of avoiding or simplifying formalities for ships that have called at a port in a third country or free zone;

- available data concerning ship traffic/movement within the Union, and/or calling at third country ports or in free zones.

The Commission submitted the Report on functioning of Directive 2010/65/EU on 25th June 2015.[16] The Report states that all the Member States have transposed the Directive 2010/65/EU and have taken initiatives regarding implementation of a national maritime single window. However, the Report contains considerable variety of single window concepts systems, approaches to create a single window and different state of play of development within the Member States.

In order to efficiently apply a national single window, it is not enough to ensure the system for electronic information exchange and link it with other interoperable systems, but it is necessary to ensure the protection of confidential data. The issue of data confidentiality and bringing the proper legal framework has shown to be a shortcoming while implementing the Directive 2010/65/EU. The success in implementing Directive 2010/65/EU partly depends on efforts of other competent bodies and on prompt implementation of measures referring to other initiatives such as the application of eManifest by customs bodies.

The part of the Report referring to the availability of data concerning ship traffic/ movement within the Union, and/or calling at third country ports or entering free zones, says that today there is no detailed information available on the extent of the traffic/ movement of ships from one EU port to another, or of ships calling intermediately at third country ports or entering free zones.

Cargo data are submitted to the customs of the ports/terminals for precisely defined purposes. Customs authorities use them for financial purposes and ports for operational purposes. The data can only be used for other purposes with the explicit permission of the person or authority providing them.

Information on cargo can be obtained on the bases of Directive 2009/42/EU of the European Parliament and of the Council on statistical returns in respect of carriage of goods and passengers by sea. [7] Directive 2009/42/EU was amended by Regulation 1090/2010/EU of the European Parliament and the Council on the amendment of the Directive 2009/42/EC on statistical returns in respect of carriage of goods and passengers by sea. [16] Regulation 1090/2010/EU introduced the obligation for Member States to deliver the data regarding maritime transport in main European ports regarding 
kinds of goods in accordance with Standard Goods Classification for Transport Statistics, 2007 (NST 2007), whereby the collecting of data regarding the goods carried by sea was brought in harmony with the approaches and standards on the road, rail, and inland waterways transport.

The second reason for bringing the Regulation is connected with the need for the Commission to be empowered to adopt delegated acts in accordance with Article 290 of the Treaty on the Functioning of the European Union, whereas a legislative act may delegate to the Commission the power to adopt non-legislative acts of general application to supplement or amend certain non-essential elements of the legislative act, while the essential elements of an area shall be reserved for the legislative act and accordingly shall not be the subject of a delegation of power (Article 290, paragraph 1 of the Treaty on the Functioning of the European Union).[15]

Since the data are confidential, they may be used for scientific purposes provided that Eurostat's guidelines for such access are fulfilled.

\section{Implementation of measures of a single maritime transport space without barriers in Croatia}

In the past ten years, Croatia has brought a series of regulations in the field of maritime affairs. Partly, the rules have been brought in order to harmonize the national legislation with international conventions and protocols in the field of maritime affairs, and partly for the purpose of Croatian accession to the European Union and the needs related with the implementation of the acquis communautaire. Today, Croatia as the Member State is obliged and called to follow initiatives and action plans brought at the EU level and take an active part in their realization. Legislative activities directed to the area of maritime transport, the reduction of administrative procedures that ships in the international and domestic service are subject to, and the establishment of the so-called "single maritime transport space without barriers" were achieved by adopting the "Ordinance on certificates, documents and data on maritime traffic, and on their delivery, collection and exchange, and on the method and conditions of granting approval for free pratique" (hereinafter: Ordinance on certificates), [13] and the Regulation on the single window for formalities in maritime transport [17].

The Ordinance on certificates was brought on 5 June 2013 whereby the EU Directives significant for establishing the navigation control system and the ship application information system were transposed in the Croatian legislation. The Ordinance introduces the Croatian Integrated Maritime Information System (CIMIS) (hereinafter: CIMIS) - the information system that ensures e-activities for ships arriving and departing between system users in the Republic of Croatia and the exchange of data with the SafeSeaNet system. As stated in Article 43, paragraph 1 of the Ordinance, the CIMIS is an integral part of the SafeSeaNet system.

The timelines assigned in Article 4, paragraph 3 of the Ordinance on certificates are completely harmonized with the regulation from the Directive 2002/59/EC. 
The Ordinance on certificates has not set out in detail the issue on reporting on dangerous goods or pollutants, yet it refers to the application of a special regulation on the handling of dangerous goods in the maritime transport. This solution can be criticized because it leads to the dispersion of provisions within several regulations which makes the application difficult as well as any future adjustments caused by changes to the basic regulations since it will consequently require amendments to regulations regarding handling of dangerous goods.

The Ordinance on certificates defines the competent body that establishes and maintains the national SafeSeaNet information system - the Authority of the Ministry competent for navigation safety. Thereby, Croatia has fulfilled the obligation from Article 22 of Directive 2002/59/EC.

Beside the Ordinance on certificates, 2015, the Regulation on a single window for formalities in maritime transport was also adopted, which transposed Directive 2010/65/EU into the Croatian legal system. The Regulation defines the manner and the conditions of harmonized delivery, exchange of certificates, documents and data by the single window for formalities in maritime transport among the ship and competent administrative authorities, among competent administrative authorities mutually and in the international data exchange. The aim is to reduce the administrative burden and to improve the quality of public services by standardization and rationalization of reporting formalities based on the principle of one-time basis delivery of certificates, documents and information. The Regulation provides definitions of the key terms needed for the implementation of the Regulation in practice. It should be noted that there is an inconsistency in the definitions of some of the aforementioned terms, starting from the idea of the ship. The definition of ship in the Regulation differs significantly from the one contained in Directive 2010/65/EU. According to the Regulation, every maritime craft on which reporting formalities are applied is considered to be a ship, whereas we come to the conclusion that it also includes floating facilities and fixed offshore facilities, all according to the definition in the Maritime Code. ${ }^{4}$ In the other part of the definition, the Regulation has gone one step forward and has declined any uncertainty regarding the status of warship, public ship or scientific research ship because it says explicitly that Regulations apply to them. This solution seems to be correct since it follows the single window subjects. The Ordinance on certificates differs from the Regulation since it does not provide the definition of the ship at all, but defines what is considered to be an anchored ship.

The single window entities are the central state administration bodies which have established, within their scope, jurisdiction over the activities at sea. Those are administrative bodies responsible for customs control, sanitary inspection, fisheries,

$4 \quad$ According to the Article 5, paragraph 1, point 2, maritime craft is a craft intended for navigation at sea (waterborne craft) or a craft permanently moored or anchored at sea (floating facility), i.e. an object entirely or partially embedded into the seabed or positioned onto the seabed (fixed offshore facility). 
veterinary, phyto-sanitary inspection, domestic affairs, environmental and nature protection, defense, foreign affairs, official statistics, general administration, culture, science and economy (Article 4. paragraph 2 of the Regulation).

The Regulation has introduced one new term, i.e. the data provider, which is not contained either in the Directive 2010/65/EU or in the Ordinance on certificates. Data provider is the authorized representative of the ship, the commander, the other person authorized by shipping company, shipping agent, representative of the cargo, the organizer of maritime transport, as well as any other natural or legal person that is obliged, by special regulations, to submit certificates, documents and data in the maritime transport. Organizer of maritime transport is also mentioned among data providers but with no additional clarifications in whose name and on whose behalf the person works. It is a term that is not contained in other regulations in the field of maritime affairs. Therefore, the authors believe that it would be appropriate to give a definition of the same in the Regulation itself.

The Regulation also says that the Single Window links the SafeSeaNet, e-Customs and other information systems. In this manner, the obligation set in Article 5 paragraph 1 of the Directive 2010/65/EU is fulfilled.

In order to achieve and maintain interoperability, compatibility and harmonization with the receipt, delivery and exchange of certificates, documents and data by a single window between data providers and relevant administrative bodies, among administrative bodies mutually and within the international data exchange, the Regulation provides forming a special body, i.e. the Inter-ministerial normative - technical committee which is, among other things, responsible for establishing and maintaining the Catalogue of certificates, documents and information provided and exchanged by a single interface.

Croatia has fulfilled the Directive 2010/65/EC requirement, it has undertaken for measures for reporting formalities to be submitted in a harmonized and coordinated manner by forming the Inter-ministerial normative - technical committee and by assigning duties to the single window entities.

Beside laws and by-laws that directly contribute to the simplification of administrative procedures in the maritime transport, regulations falling within the jurisdiction of other ministries and administrative bodies that regulate a specific area of maritime domain should also be taken into consideration. Methodological basics for statistical survey of traffic in seaports is the example of such regulations. [12]

Pursuant to Article 43 of the Official Statistics Act, the Central Bureau of Statistics issued Methodological basics for statistical research of traffic in seaports in 2013.[18] Statistical survey of traffic in seaports is carried out methodologically in accordance with Directive 2009/42/EC regarding statistical returns in respect of the carriage of goods and passengers by sea. ${ }^{5}$

5 Directive 2009/42/EC on statistical returns in respect of carriage of goods and passengers by sea has been amended three times: by Regulation 1090/2010/EU of European Parliament and of the Council of 24 November 2010 amending Directive 2009/42/EC on statistical returns in respect 
According to Article 3, paragraph 1 of the Methodological basics, the Central Bureau of Statistics collects data on transport of passengers and goods on ships calling at the sea ports of the Republic of Croatia. Transport of goods and passengers understands the movement of goods and passengers using maritime vessels, on voyages that completely or partly take place at sea. The term goods also encompasses goods transported in offshore installations and the goods taken from the sea bed and unloaded in the port. Motor fuel and supplies for the vessel are excluded from the scope of Methodological basics.

The Republic of Croatia has not used the possibility to be excluded from certain group of ships as provided by Article 3 of Directive 2009/42/EC on statistical returns in respect of carriage of goods and passengers by sea, therefore, the procedure includes vessels with a gross tonnage of less than 100 .

The data obtained via statistical survey, including confidential data, are sent to Eurostat. Confidential data are defined by Article 4, point 23 of Official Statistics Act. Confidential data are those ones that enable direct or indirect identification of statistical units while discovering individual information.

Statistical unit represents the observed basic unit the data refer to. It can represent natural person, legal person, craftsman, state body, or body of a local or regional selfgovernment unit.

In order to define whether is possible to make the identification of the statistical unit, all the relevant data are taken in consideration in order to enable the third party to reasonably use it for the identification of the statistical unit.

\section{Conclusion}

Bringing numerous strategic documents at the EU level that represent the political framework and the basis for adopting legislative measures has enabled the creation of a single European maritime transport space without barriers. Directive 2010/65/EU on reporting formalities for ships arriving in and/or departing from ports of the Member States and repealing Directive 2002/6/EC was adopted as one of the key measures of the EU for the realization of the Blue Belt, meaning the creation of the European maritime transport space without barriers.

Extreme efforts have been made in order to establish the vessel traffic monitoring and information system. The process started 20 years ago, and has been intensified

of carriage of goods and passengers by sea, by Commission Decision 2010/2167EC of 14 April 2010, amending Directive 2009/42/EC on statistical returns in respect of carriage of goods and passengers by sea, by Commission Delegated Decision 2012/186/EU of 3 February 2012, amending Directive 2009/42/EC on statistical returns in respect of carriage of goods and passengers by sea. Since the amendments have been brought before 2013, by bringing Methodological basics for the statistical survey of traffic in seaports, European solutions on statistical data and reports have been transposed into the Croatian legal system completely. 
by the adoption of Directive 2002/59/EC establishing the Community vessel traffic monitoring and information system and its subsequent changes and amendments.

Legislative activities of the Republic of Croatia aimed at reducing administrative burdens of ships engaged in both the international and domestic voyages and the establishment of the so-called single maritime transport space without barriers has been achieved by adopting the Ordinance on certificates, documents and data on maritime traffic, and on their delivery, collection and exchange, and on the method and conditions of granting approval for free pratique and Regulation on the single window for formalities in maritime transport.

Requirements set in the Directive 2002/59/EC and its amendments, as well as requirements set in the Directive 2010/65/EU have been transferred into the Croatian legal system by the above mentioned implementing regulations. The authors conclude that the Croatian legal framework is in compliance with European standards. The Ordinance on the documents and the Regulation on the single window for formalities in maritime transport decreased administrative burdens for ships dealing with Croatian ports, and also increased the level of safety of navigation as well as concern about the protection of the marine environment. The comparative overview of solutions contained in the directives and Croatian bylaws defined certain conceptual and content mismatches (the term ship, organizer of maritime transport) which can lead to legal uncertainty and diverse applications and procedures in their daily work, therefore, the authors suggest harmonization of terms used in different, but content-related regulations and their consistent application.

\section{References}

1. White Paper Roadmap to a Single European Transport Area - Towards a competitive and resourse efficient transport system, COM (2011) 144 final, Brussels, 28.3.2011.

2. Directive $2000 / 59 / \mathrm{EC}$ of the European Parliament and of the Council on port reception facilities for ship-generated waste and cargo residues, OJ L 332, 28.12.2000., www.eur-lex.europa.eu

3. Directive 2002/59/EC of the European Parliament and of the Council of 27 June 2002 establishing a Community vessel traffic monitoring and information system and repealing Council Directive 93/75/EEC, OJ L 208, 5.8.2002., www.eur-lex.europa.eu

4. Directive 2009/17/EZ of the European Parliament and of the Council amending Directive 2002/59/ EC of the European Parliament and of the Council establishing a Community vessel traffic monitoring and information system, OJ L 131, 28.5.2009., www.eur-lex.europa.eu

5. Commission Directive 2014/100/EU amending Directive 2002/59/EC of the European Parliament and of the Council establishing a Community vessel traffic monitoring and information system, OJ L 308/82, 29.10.2014., www.eur-lex.europa.eu

6. Directive 2010/65/EU of the European Parliament and of the Council of 20 October 2010 on reporting formalities for ships arriving in and/or departing from ports of the Member States and repealing Directive 2002/6/EC, OJ L 283, 29.10.2013., www.eur-lex.europa.eu

7. Directive 2009/42/EC of the European Parliament and of the Council of 6 May 2009 on statistical returns in respect of carriage of goods and passengers by sea, OJ L 14, 6.6.2009., www.eur-lex. europa.eu

8. Communication from the Commission to the European Parliament, the Council, the European Economic and Social Committee and the Committee of the Regions, Single Market Act II, Together for new growth, COM (2012) 537 final, Brussels, 3.10.2012. 
9. Communication from the Commission to the European Parliament, the Council, the European Economic and Social Committee and the Committee of the Regions, Communication and action plan with a view to establishing a European maritime transport space without barriers, COM (2009) 11 Final, Brussels, 21.1.2009.

10. Communication from the Commission Blue Belt, a Single Transport Area for shipping, COM (2013), 510 final, Brussels, 8.7.2013.

11. Convention on Facilitation of International Maritime Traffic, International Agreements - Official Gazette No.1/92.

12. Methodological basics for the statistical survey of traffic in seaports, Official Gazette No. 20/13.

13. Ordinance on certificates, documents and data on maritime traffic, and on their delivery, collection and exchange, and on the method and conditions of granting approval for free pratique, Official Gazette No.70/13, 55/15.

14. Report from the Commission to the European Parliament and the Council on the functioning of Directive 2010/65/EU on reporting formalities for ships arriving in and/or departing from ports of the Member States, COM (2014) 320 final, Brussels, 25.6.2014.

15. Treaty on the Functioning of the European Union, www.eurolex.

16. Regulation (EU) No 1090/2010 of the European Parliament and of the Council of 24 November 2010 amending Directive 2009/42/EC on statistical returns in respect of carriage of goods and passengers, OJ L 325, 9.12.2010.

17. Regulation on the single window for formalities in maritime transport, Official Gazette No. 119/15.

18. Official Statistics Act, Official Gazette No.12/13. 
Biserka Rukavina, Loris Rak, Silvana Buneta

\section{Pravni okvir uspostave jedinstvenog prostora za pomorski prijevoz bez prepreka}

\section{Sažetak}

U radu se daje pregled aktivnosti Europske komisije za uspostavu jedinstvenoga europskog prostora za pomorski prijevoz te se ukazuje na činjenicu jesu li i u kojoj mjeri usvojeni strateški dokumenti saživjeli u praksi.

Posebno se analiziraju Direktiva 2010/65/EU Europskog parlamenta i Vijeća o službenom postupku prijave za brodove koji dolaze u luke i/ili odlaze iz luka država članica i o stavljanju izvan snage Direktive 2002/6/EZ i Direktive 2002/59/EZ Europskog parlamenta i Vijeća o uspostavi sustava nadzora plovidbe i informacijskog sustava Zajednice koje predstavljaju značajna zakonodavna postignuća Europske unije u procesu smanjenja administrativnih opterećenja kojima su izloženi brodovi u pomorskom prijevozu. Posebno se obrazlažu razlozi izmjene Direktive 2002/59/EZ.

U posljednjem dijelu rada autori preispituju postignuća Republike Hrvatske u provedbi mjera za uspostavu jedinstvenoga europskog prostora za pomorski prijevoz. Komparativnim prikazom rješenja sadržanih u direktivama i hrvatskim podzakonskim aktima autori ukazuju na postojanje neusklađenosti i potrebe daljnjeg djelovanja.

Ključne riječi: jedinstveni europski prostor za pomorski prijevoz, Direktiva 2010/65/EU, Direktiva 2002/59/EZ, hrvatski pravni okvir 